НАУКОВИЙ ВІСНИК

Scientific messenger of Lviv National University of
Veterimary Medicicie and Biotechnologies
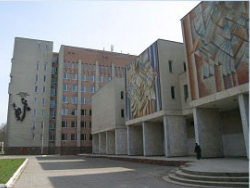

Науковий вісник Аьвівського національного університету ветеринарної медицини та біотехнологій імені С.3. Гжицького. Серія: Ветеринарні науки

Scientific Messenger of Lviv National University of Veterinary Medicine and Biotechnologies. Series: Veterinary sciences

UDC 636.32/.38:616.99(477.53)

\title{
Distribution and nosological profile of nematodoses of the digestive tract of sheep in farms of Poltava region
}

\author{
V. Melnychuk ${ }^{1}$, V. Yevstafieva ${ }^{1}$, I. Yuskiv ${ }^{2}$, O. Zhulinska ${ }^{3}$ \\ ${ }^{1}$ Poltava State Agrarian University, Poltava, Ukraine \\ ${ }^{2}$ Stepan Gzhytskyi National University of Veterinary Medicine and Biotechnologies Lviv, Ukraine \\ 3 "Ascania-Nova” Institute of Animal Breeding in the Steppe Regions named after M. F. Ivanov-National Scientific \\ Selection-Genetics Center for Sheep Breeding, Ascania-Nova, Ukraine
}

Article info

Received 18.10.2021

Received in revised form 18.11.2021

Accepted 19.11.2021

Poltava State Agrarian University, Skovorody Str., 1/3, Poltava, 36003, Ukraine.

Tel.:+38-066-674-78-09

E-mail:melnychyk86@ukr.net

Stepan Gzhytskyi National University of Veterinary Medicine and Biotechnologies Lviv, Pekarska Str., 50, Lviv, 79010, Ukraine

“Ascania-Nova” Institute of Animal Breeding in the Steppe Regions named after M. F. Ivanov - National Scientific SelectionGenetics Center for Sheep Breeding, Soborna Str., 1,

Ascania-Nova, Chaplinka district Kherson region, 75230, Ukraine.
Melnychuk, V., Yevstafieva, V., Yuskiv, I., \& Zhulinska, O. (2021). Distribution and nosological profile of nematodoses of the digestive tract of sheep in farms of Poltava region. Scientific Messenger of Lviv National University of Veterinary Medicine and Biotechnologies. Series: Veterinary sciences, 23(104), 119-125. doi: 10.32718/nvlvet10419

This study aimed to study the current state of the fauna of pathogens of nematodoses of the digestive tract of sheep in the Poltava region. The work was performed based on the Laboratory of the Department of Parasitology and Veterinary Sanitary Examination of Poltava State Agar University and in the conditions of sheep farms of various forms of ownership in the Poltava region. According to the conducted research, for the first time, a detailed description of the fauna of nematodes parasitizing in the gastrointestinal tract of sheep in the climatic conditions of the Poltava region is given. Generic and species identification of isolated helminths was performed. Indicators of intensity and invasions and abundance index of detected nematodoses of sheep were established. It was determined that the fauna of nematodes of the digestive tract of sheep is represented by 15 species of helminths belonging to 2 classes: Adenophorea and Secernentea, 5 series: Trichurida, Enoplida, Strongylida, Rhabditida, Oxyurida, and 12 genera: Trichuris, Haterongia, Haemonchus Trichostrongylus, Nematodirus, Aonchotheca, Oesophagostomum, Scriabinema, Chabertia, Strongyloides, Cooperia, Bunostomum. Detected nematodes are geohelminths that cause the following diseases in sheep: trichuriasis, haemonchosis, ostertagiosis, trichostrongylosis, nematodirosis, oesophagostomosis, chabertiosis, cooperosis, bunostomosis, scriabinemosis, capillariasis, and strongyloidosis. It was found that the total infestation of sheep by nematodes was $78.10 \%$, the intensity of the invasion ranged from 1 to 93 specimens, and the abundance index - from 0.01 to 21.39 samples. The most common in the study region were nematodes of four species: $H$. contortus ( $P-60.81 \%, I I-24.15$ spec./head, AI - 14.69 spec.), O. circumcincta $(P-60.81 \%, I I-29.75$ spec./head, AI- 18.09 spec.), T. colubriformis $(P-59.08 \%, I I-$ 36.21 spec./head, AI - 21.39 spec.) and T. ovis (P-55.04\%, II - 24.19 spec./head, AI - 13.31 spec.). Isolated nematodes of $T$. colubriformis and $H$. contortus are pathogens of zooanthroponoses and are dangerous to humans, indicating the study's relevance and importance. The obtained scientific data will increase the effectiveness of measures to control and prevent nematodoses of the gastrointestinal tract of sheep in farms of the Poltava region.

Key words: sheep, nematodoses of digestive tract, fauna, distribution, prevalence, invasion intensity, abundance index.

\section{Поширення та нозологічний профіль нематодозів травного каналу овець у господарствах Полтавської області}

\author{
В. В. Мельничук ${ }^{1}$, В. О. Євстаф’єва ${ }^{1}$, І. Д. Юськів ${ }^{2}$, О. С. Жулінська ${ }^{3}$
}

${ }^{1}$ Полтавський державний аграрний університет, м. Полтава, Україна 
${ }^{2}$ Львівський національний університет ветеринарної медицини та біотехнологій імені С. 3. Гжицького, м. Львів, Україна

${ }^{3}$ Інститут тваринництва степових районів імені М. Ф. Іванова “Асканія-Нова” - Національний науковий селекційно-генетичний центр з вівчарства, с. м. т. Асканія-Нова, Україна

Метою даного дослідження було вивчити сучасний стан фауни збудників нематодозів травного тракту овецьь на території Полтавської області. Роботу виконували на базі лабораторії кафедри паразитології та ветеринарно-санітарної експертизи Полтавського державного агарного університету та в умовах вівцегосподарств різної форми власності на території Полтавської області. За даними проведених досліджень вперше надано детальний опис фауни нематод, щяо паразитують у илунковокишковому тракті овець У кліматичних умовах Полтавської області. Здійснено родову та видову ідентифікацію виділених гельмінтів. Встановлено показники екстенсивності й інтенсивності інвазій та індексу рясності за виявлених нематодозів овець. Визначено, щчо фауна нематод травного тракту овець представлена 15 видами гельмінтів, які відносяться до 2-х класів: Адепорһогеа й Secernentea, 5-ти рядів: Trichurida, Enoplida, Strongylida, Rhabditida, Oxyurida, ma 12 podis: Trichuris, Haemonchus, Ostertagia, Trichostrongylus, Nematodirus, Aonchotheca, Oesophagostomum, Skrjabinema, Chabertia, Strongyloides, Cooperia, Bunostomum. Buявленi нематоди є геогельмінтами, що викликають у овець наступні захворювання: трихуроз, гемонхоз, остертагіоз, трихостронгільоз, нематодіроз, езофагостомоз, хабертіоз, коопероз, буностомоз, скрябінемоз, капіляріоз та стронгілоїоо. Встановлено, щзо загальна інвазованість овець нематодами становила 78,10\%, показники інтенсивності інвазї коливалися в межах від 1 до 93 екземплярів, а індексу рясності - від 0,01 до 21,39 екземплярів. Найбільш поширеними в умовах дослідженого регіону виявилися нематоди чотирьох видів: H. contortus (EI - 60,81\%, II - 24,15 екз/гол., IP - 14,69 екз), O. circumcincta (EI - 60,81\%, II -29,75 екз/гол., IP 18,09 екз), T. colubriformis (EI- 59,08\%, II - 36,21 екз/гол., IP - 21,39 екз) та T. оvis (EI- 55,04\%, II - 24,19 екз/гол., IP - 13,31 екз). Виділені нематоди видів T. colubriformis ma H. contortus є збудниками зооантропонозів і небезпечні для людини, що вказує на актуальність $i$ важливість проведених досліджень. Отримані наукові дані дозволять підвищити ефективність проведення заходів щцодо боротьби та профілактики нематодозів шлунково-кишкового тракту овець у господарствах Полтавської області.

Ключові слова: вівці, нематодози травного каналу, фауна, поширення, екстенсивність інвазї, інтенсивність інвазї, індекс ряcності.

\section{Вступ}

Вивчення фауни паразитів різних видів тварин, а також питань взаємовідносин збудників між собою, впливу на них факторів зовнішнього середовища та особливостей їх поширення має як теоретичне, так i практичне значення. Особливо це важливо при розробці заходів щодо боротьби 3 паразитарними хворобами в різних клімато-географічних регіонах, зокрема і в Україні.

Наразі, однією з причин, що певним чином стримує розвиток галузі вівчарства, є інвазійні хвороби, в тому числі нематодози травного тракту. Вплив антропогенного чинника на епізоотичну ситуацію щодо нематодозів овець загрожує зростанням чисельності популяції збудників паразитарних захворювань та збільшенням ризику зараження ними тварин як в Україні, так й інших країнах світу (Byrka \& Berezovskyi, 2003; Abakar et al., 2008; Bohach et al., 2015).

Вагомий економічний збиток галузі вівчарства завдають кишкові гельмінтози, серед яких провідне місце займають нематодози травної системи (Eslami et al., 1979; Gupta et al., 1987; Idris et al., 2012).

Нематодози травного тракту овець широко розповсюджені в більшості країн світу. Зокрема, на території Ефіопії науковцями серед поголів'я овець виділено 7 родів гельмінтів: Haemonchus, Trichostrongylus, Ostertagia, Oesophagastamum, Trichuris, Chabertia, та Bonustomum, ураженість тварин якими становила $37,4 \%, 26,2 \%, 16,8 \%, 9,3 \%, 7,9 \%, 4,2 \%$ та $2,3 \%$ відповідно (Ibrahim et al., 2014). За повідомленнями бразильських вчених відомо про інвазованість овець у штаті Санта-Катаріна 14 видами нематод, серед яких, найбільш поширеними виявилися H. contortus (100\%), T. circumcincta (100\%), O. ostertagi (100\%), T. colubriformis $\quad(100 \%), \quad$ N. spathiger $\quad(100 \%)$, Oe. venulosum (100\%), T. ovis $(100 \%)$ та T. axei
(98,7 \%) (Ramos et al., 2004). У південних регіонах Польщі фауна нематод травного тракту овець, за повідомленнями дослідників, представлена трьома родинами: Trichostrongylidae (Trichostrongylus spp., Ostertagia spp., Nematodirus spp., Cooperia spp., Haemonchus contortus), Strongylidae (Oesophagostomum spp., Strongyloides papillosus, Chabertia ovina) та Ancylostomatidae (Bunostomum spp.). 3-поміж виділених нематод роди Trichostrongylus, Ostertagia й Nematodirus виявилися найбільш поширеними (Balicka-Ramisz et al., 2013).

В умовах північно-східних районів Білорусії вівці уражені переважно збудниками стронгілідозів травного каналу (ЕI - 43,5 \%) й стрнгілоїдозу $(32,4 \%)$. Автори також відмічають, що збудники трихурозу та капіляріозу серед поголів'я овець реєструються значно рідше (11,8 та $6,5 \%$ відповідно) (Kovalevskaja et al., 2016). Також, нематодози травного каналу овець $€$ досить розповсюдженими на території Російської Федерації. Зокрема, представники родів Chabertia, Nematodirus, Haemonchus, Trichostrongylus, Ostertagia, Cooperia, Trichuris й Bunostomum набули найбільшого поширення (Terentieva, 2011; Believ et al., 2012; Salmanova \& Gajrabekov, 2013).

На території України вивченню фауни гельмінтів овець за період iї незалежності присвячені лише окремі наукові роботи. Так, в умовах Дніпропетровської області у овець виділено 4 види паразитів травної системи: Nematodirus spp., H. contortus, Trichuris spp. та S. papillosus (Boyko, 2015). На території Сумської області науковцями за результатами паразитологічних досліджень овець виявлено збудників стронгілідозів травного каналу 7 родів, а саме: Trichostrongylus, Nematodirus, Ostertagia, Chabertia, Oesophagostomum, Bunostomum (Vlasenko \& Stybel, 2012), а у овець в господарствах Полтавської області - нематод роду Nematodirus, Trichuris, S. papillosus та стронгілід тра- 
вного каналу (без визначення видової належності) (Yevstafieva et al., 2016).

Необхідно відзначити, що в Україні дослідження щодо фауни збудників нематодозів травного каналу овець та їх епізоотологічних особливостей на сьогодні мають фрагментарний характер, недостатньо розкриті питання фауни збудників.

У зв'язку з вищенаведеним, необхідним й актуальним залишається питання щодо вивчення сучасного стану фауни збудників нематодозів травного каналу овець в окремих регіонах України, їх структури, що має важливе значення для розробки заходів боротьби 3 ними. Тому метою наших досліджень було встановити сучасний стан фауни нематодозів травного тракту овець на території Полтавської області.

\section{Матеріал і методи досліджень}

Вивчення епізоотичної ситуації щодо нематодозів травного каналу овець здійснювали впродовж 20152021 років на базі лабораторії кафедри паразитології та ветеринарно-санітарної експертизи Полтавського державного аграрного університету та в умовах вівцегосподарств різної форми власності Полтавської області (Диканського, Зіньківського, Кобеляцького, Котелевського, Миргородського, Полтавського, Семенівського, Новосанжарського, Чутівського й Шишацького районів). Досліджували овець порід романівська, асканійська тонкорунна та курдючна віком від 2 місяців до 5 років.

3 метою визначення видового складу збудників нематодозів травного каналу овець проводили збір гельмінтів методом повного гельмінтологічного розтину органів шлунково-кишкового тракту загиблих або вимушено забитих овець за методом К. І. Скрябіна (Skriabyn, 1928). Після вилучення 3 кишечнику нематод промивали у $0,9 \%$ розчині $\mathrm{NaCl}$ та фіксували за загальноприйнятою методикою гарячим $70 \%$ етиловим спиртом (Ivashkin et al., 1971). Інвазованість овець збудниками нематодозів травного тракту визначали за показниками екстенсивності інвазії (ЕI, \%), інтенсивності інвазії (II, екз./гол.) та індексу рясності (IP, екз./гол.). Ідентифікацію видової належності нематод травного тракту овець проводили згідно диференційних визначників (Skrjabin et al., 1954; Ivashkin et al., 1998).

Всього досліджено 347 комплектів органів травного каналу овець (від кожної тварини досліджували сичуг, а також тонкий і товстий відділи кишечнику).

Усі маніпуляції з тваринами проводили відповідно до Європейської конвенції про захист хребетних тварин, які використовуються для експериментальних i наукових цілей (Official Journal of the European Union L276/33, 2010).

\section{Результати та їх обговорення}

За результатами гельмінтологічного розтину органів травного каналу овець, що утримувалися у вівцегосподарствах Полтавської області, встановлено значне поширення нематод травного каналу. Таксономічна структура виділених нематод представлена 15 видами гельмінтів, що відносяться до 2-х класів Adenophorea (20,88\%) та Secernentea (79,12\%), 5-ти рядів Strongylida (Railliet et Henry, 1913), Trichurida ((Skrjabin et Schulz, 1928) Spassky, 1954), Oxyurida (Skrjabin, 1923), Enoplida (Filipjev, 1929) та Rhabditida (Chitwood, 1933). Їх відсоткове співвідношення в загальній структурі гельмінтокомплексу становила відповідно 72,33 \%, 19,59\%, 6,44 \%, 1,29\% та 0,35\%.

Слід зазначити, що виявлені нематоди належали до 12 родів, 3-поміж яких найбільшу частку $(15,12 \%)$ становили збудники, які відносяться до роду Trichuris Roederer, 1761 (рис. 1.).

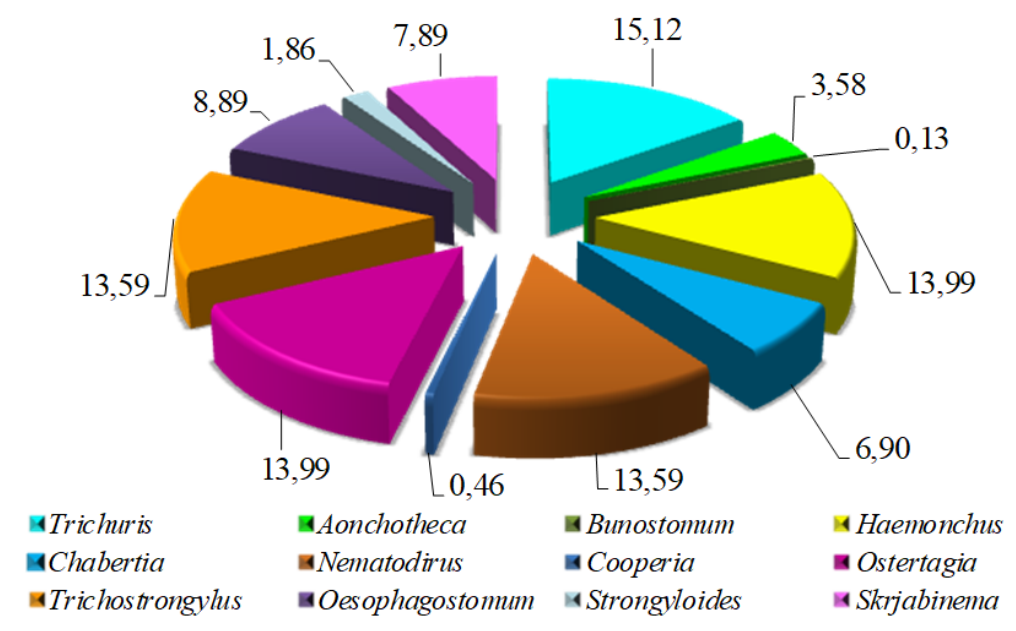

Рис. 1. Співвідношення різних родів збудників нематодозів травного каналу овець, \%

Частка родів Haemonchus Cobb, 1898 й Ostertagia Ransom, 1907 та Trichostrongylus Looss, 1905 й Nematodirus Ransom, 1907 становила по 13,99\% та 13,59 \% відповідно. Дещо меншу частку займали роди Oesophagostomum Pearse, 1916, Skrjabinema
Verestchagin, 1926, Chabertia Railliet \& Henry, 1909, Aonchotheca López-Neyra, 1947 i Strongyloides Grassi, 1879 - 8,89\%, 7,89\%, 6,90\%, 3,58 \% і 1,86\% відповідно. Найменшою виявилася частка родів Coоperia 
Ransom, 1907 й Bunostomum Railliet, 1902 - 0,46 та 0,13\% відповідно.

Дослідженнями встановлено, що ураженість тварин збудниками нематодозів травного каналу на території досліджуваної області в середньому становила $78,10 \%$ (табл. 1$)$.

\section{Таблиця 1}

Поширення нематодозів травного каналу овець в умовах Полтавської області, $\mathrm{n}=347$

\begin{tabular}{lcc}
\hline \multicolumn{1}{c}{ Збудники } & Інвазовано, голів & EI, $\%$ \\
\hline T. ovis & 191 & 55,04 \\
T. skrjabini & 82 & 23,62 \\
T. globulosa & 73 & 21,04 \\
\hline \multicolumn{1}{c}{ Bсього Trichuris sp. } & 228 & 65,71 \\
\hline B. trigonocephalum & 2 & 0,58 \\
H. contortus & 211 & 60,81 \\
O. circumcincta & 211 & 60,81 \\
T. colubriformis & 205 & 59,08 \\
N. spathiger & 153 & 44,09 \\
N. abnormalis & 11 & 3,17 \\
\hline Bсього Nematodirus sp. & 156 & 44,96 \\
\hline Cooperia sp. & 7 & 2,02 \\
Oe. venulosum & 134 & 38,62 \\
Ch. ovina & 104 & 29,97 \\
\hline Bсього Strongylida & 271 & 78,10 \\
\hline A. bovis & 54 & 15,56 \\
Sk. ovis & 119 & 34,29 \\
S. papillosus & 28 & 8,07 \\
\hline \multicolumn{1}{c}{ Всього } & 271 & 78,10 \\
\hline
\end{tabular}

3-поміж нематодозів травного каналу овець найбільш часто реєстрували трихурозну (ЕІ - 65,71\%), гемонхозну, остертагіозну та трихостронгільозну (ЕІ від 59,08 до 60,81\%) інвазії (рис. 2).

Встановлено, що захворювання овець на трихуроз викликали нематоди T. ovis, T. skrjabini та T. globulosa, показники екстенсивності інвазій становили $55,04 \%, 23,62 \%$ та $21,04 \%$ за II - 24,19 1,02 екз/гол., $27,77 \pm 1,53$ та $13,40 \pm 0,76$ екз/гол. відповідно (за коливань від 1 до 70 екз).

Серед стронгілідозів травного каналу домінуючими захворюваннями виявилися гемонхоз, остертагіоз та трихостронгільозу, що були викликані збудниками H. contortus, O. circumcincta та T. colubriformis. Ураженість тварин цими нематодами сягала понад $50 \%$. Зокрема, показники екстенсивності та інтенсивності інвазії становили за гемонхозу - 60,81\% та $24,15 \pm$ 1,19 екз/гол., остертагіозу - $60,80 \%$ та $29,75 \pm$ 1,47 екз/гол., трихостронгільозу - 60,80 \% та 36,21 \pm 1,43 екз/гол. (за коливань від 1 до 93 екз).

Дещо менше реєстрували нематодіроз, езофагостомоз та хабертіоз. Зокрема, нематодірозну інвазію діагностовано у 44,96 \% досліджених тварин, де збудниками були два види N. spathiger та N. abnormalis, а EI становила 44,09 та $3,17 \%$ за II $-22,00 \pm 1,01$ та $10,18 \pm 1,62$ екз/гол. відповідно (за коливань від 1 до 60 екз). Збудником езофагостомозу виявився один вид Oe. venulosum, який встановлено у $38,62 \%$ овець за II - 30,07 \pm 1,23 екз/гол. (за коливань від 1 до 81 екз). Хабертіоз, викликаний Ch. ovina, діагностовано у
29,97 \% тварин за II $-26,15 \pm 1,44$ екз/гол. (за коливань від 3 до 60 екз).

Рідше (до 5 \%) серед стронгілідозів травного каналу овець діагностували коопероз та буностомоз, збудниками яких були Cooperia sp. та B. trigonocephalum, де ЕI становила 2,02 та $0,58 \%$ за II $-5,86 \pm 1,26$ та $2,00 \pm 1,00$ екз/гол. відповідно (за коливань від 1 до 11 екз).

Окрім того, в овець діагностували скрябінемоз, капіляріоз та стронгілоїдоз, збудниками яких були види A. bovis, Sk. ovis та S. papillosus, де EI становила $34,29 \%, 15,56 \%$ та 8,07 \% за II $-21,76 \pm 1,10$ екз/гол., $9,61 \pm 0,65$ екз/гол. та 4,96 $\pm 0,46$ екз/гол. відповідно (за коливань від 1 до 54 екз).

Показники індексу рясності (IP) шлунковокишковими нематодами характеризувалися найбільшим розповсюдженням серед популяції домашніх овець нематод видів T. colubriformis (21,39 екз/гол.), O. circumcincta (18,09 екз/гол.), H. contortus (14,69 екз/гол.), T. ovis (13,31 екз/гол.) та Oe. venulosum (11,61 екз/гол.). Індекс рясності видів T. globulosa, T. skrjabini, S. ovis, Ch. ovina, N. spathiger був незначним, і коливався в межах від 2,82 до 7,84 екз/гол. Нематоди видів A. bovis, B. trigonocephalum, N. abnormalis, Cooperia sp. peєстрували рідко, де IP не перевищував 1,50 екз/гол.

Отже, нематодози травного тракту є досить поширеними хворобами овець на території Полтавської області. Домінуючими виявилися стронгілідози (ЕІ $78,10 \%$ ) 3 переважанням в нозологічній структурі інвазій гемонхозу, остертагіозу, трихостронгільозу та трихурозу (ЕI - 65,71\%).

Як відомо, вівчарство $є$ важливою галуззю сільського господарства багатьох країн світу. Значних збитків цій галузі тваринництва завдають гельмінтози, серед яких найпоширенішими $\epsilon$ шлунково-кишкові нематодози (Vlassoff et al., 2001; Banerjee et al., 2009). Варто зазначити, що біорізноманіття фауни гельмінтів у овець та інших видів тварин залежить від багатьох факторів, таких як: видові особливості, біотичні, абіотичні та технологічні чинники, тощо (Cabaret et al., 2002; Thieltges et al., 2008). Так, інвазованість овець, вирощених у місті Ботукату, що на південному сході Бразилії, окремими видами нематод травного каналу сягає $100 \%$ (Wilmsen et al., 2014), а на території Ефіопії - до 86,9\% (Shankute et al., 2013; Tigist et al., 2015). На території Сербії показники ураженості овець нематодами травного каналу: Nematodirus sp., Ostertagia sp., Trichostrongylus sp., Haemonchus sp., Chabertia ovina, Oesophagostomum sp., Marshallagia sp., Cooperia sp., Bunostomum sp. й Skrjabinema sp. коливалися в межах від 13,66 до 71,22\%. Водночас, найбільш поширеними (60,11-71,22\%) виявилися нематоди Nematodirus sp., Ostertagia sp., Trichostrongylus sp., Haemonchus sp. й Chabertia ovina (Pavlovic, 2017).

Проведеними нами дослідженнями встановлено, що на території Полтавської області 78,08 \% овець виявилися ураженими нематодами травного тракту. Фауна гельмінтів травної системи овець представлена 15 видами нематод, які відносяться до 5-ти рядів 
(Trichurida, Enoplida, Strongylida, Rhabditida та Oxyurida) та 12 родів (Trichuris, Haemonchus, Ostertagia, Trichostrongylus, Nematodirus, Aonchotheca, Oesophagostomum, Skrjabinema, Chabertia, Strongyloides, Cooperia, Bunostomum). Вперше на території Полтавської області у домашніх овець (Ovis aries) виявлено нематод Trichuris globulosa (Linstow, 1901) та Aonchotheca bovis [= Capillaria bovis $]$ (Schnyder, 1906), де показники ЕІ були незначними 21,04 та 15,56 \% відповідно. Такі показники ураженості овець цими нематодами, а також домінування T. ovis й T. skrjabini (EI - 55,04 й 23,62 \% відповідно) над $T$. globulosa пояснюється авторами особливостями, що пов'язані з циклом їх розвитку (Yevstafieva et al., 2018; Melnychuk \& Berezovsky, 2018). 3 виділених нами нематод найпоширенішими виявилися $H$. contortus й O. circumcincta $(60,81 \%)$, T. colubriformis $\quad(59,08 \%), \quad$ T. ovis $\quad(55,04 \%)$, N. spathiger (44,09\%), Oe. venulosum $(38,62 \%)$, S. ovis (34,29\%), Ch. ovina (29,97\%), T. skrjabini (23,62\%) та T. globulosa (21,04\%). Інші види A. bovis, S. papillosus, $N$. abnormalis, Cooperia sp. й B. trigonocephalum виявляли рідше (ЕI - 0,58-15,56\%).

Варто зазначити, що виділені види H. contortus i T. colubriformis, які $є$ збудниками зооантрапонозів, були найбільш поширеними на території Полтавської області, що, ще раз доводить актуальність проведених нами досліджень. Згідно даних авторів, кількість, співвідношення видів нематод травного каналу, показники ураженості овець у конкретному біоценозі залежать від гельмінтофауністичного комплексу, що є типовим для певної екосистеми. Ї̈і природнокліматичні умови впливають та регулюють розвиток ембріональних чи постембріональних стадій гельмінтів у зовнішньому середовищі в паразитарній ланці “яйце - інвазійне яйце” або ж “яйце - личинка - інвазійна личинка" (Mederos et al., 2010; Morgan \& van Dijk, 2012).

Безперечно, в епізоотологічному відношенні правильно розглядати не лише показники екстенсивності інвазії, але, також враховувати показники інтенсивності інвазії та індексу рясності паразитів. Відомо, що від інтенсивності інвазії залежить ступінь патологічних змін в органах та тканинах, а також тривалість відновлення порушених фізіологічних функцій в організмі господаря після проведених лікувальних заходів. Крім того, базуючись на цих показниках, ветеринарний фахівець визначає домінуючі види збудників при асоційованих гельмінтозах, що надзвичайно важливо для правильного підбору лікувального засобу. Від цього багато в чому залежить успіх боротьби 3 гельмінтозами (Waruiru et al., 2001; Kanyari et al., 2009).

Нами встановлено, що показники інтенсивності інвазії у заражених овець коливалися в межах від 1 до 93 екземплярів, індексу рясності - від 0,01 до 21,39 екземплярів. Причому, в овець виявили максимальну кількість нематод видів T.colubriformis, O.circumcincta, Oe. venulosum, T. ovis, T. skrjabini, Ch. ovina та H. contortus, де II коливалася в межах від 24,15 $\pm 1,19$ до $36,21 \pm 1,43$ екз/гол. Інтенсивність інвазії $S$. ovis,
N. spathiger, T. globulosa, N. abnormalis не перевищувала $22,00 \pm 1,01$ екз/гол, а B. trigonocephalum, S. papillosus, Cooperia sp. та A. bovis - 9,61 $\pm 0,65$ екз/гол. У той же час, показники індексу рясності нематод травного каналу характеризувалися найбільшим розподілом серед поголів'я овець видів T. colubriformis, O. circumcincta, H. contortus, T. ovis та Oe. venulosum (11,6121,39 екз/гол.). Індекс рясності видів T. globulosa, T. skrjabini, S. ovis, Ch. ovina, N. spathiger не перевищував 7,84 екз/гол., а A. bovis, B. trigonocephalum, N. abnormalis та Cooperia sp., - 1,50 екз/гол. На нашу думку, такий розподіл показників пов'язаний із пристосованістю нематод того чи іншого виду, особливо їх екзогенних стадій розвитку, до умов зовнішнього середовища, а також їх стійкістю відносно несприятливих абіотичних факторів.

\section{Висновки}

Нематодози травного тракту є поширеними інвазіями овець на території господарств Полтавської області, середня екстенсивність інвазії становила 78,10\%. Фауна збудників нематодозів представлена збудниками стронгілідозів органів травлення (H. contortus, O. circumcincta, T. colubriformis, N. spathiger, N. abnormalis, Oe. venulosum, Ch. ovina, B. trigonocephalum та Cooperia sp.) трихурозу (T. ovis, T. skrjabini та T. globulosa), стронгілоїдозу (S. papillosus), скрябінемозу (S. ovis) та капіляріозу (A. bovis). Найбільш поширеними видами серед нематод, які паразитують у шлунково-кишковому тракті овець у кліматичних умовах Полтавської області, $\epsilon$. contortus й O. circumcincta (екстенсивність інвазії склала $60,81 \%)$, T. colubriformis $(59,08 \%)$ та T. ovis $(55,04 \%)$.

Перспективи подальших досліджень. В перспективі планується встановити ефективність науково обгрунтованих лікувально-профілактичних заходів у вівцегосподарствах Полтавської області з урахуванням встановленої фауни нематод.

Відомості про конфлікт інтересів. Автори стверджують про відсутність конфлікту інтересів щодо їх вкладу та результатів досліджень.

\section{References}

Abakar, A. D., Almalaik, A. H. A., \& Bashar, A. E. (2008). Prevalence and Dynamics of Some Gastrointestinal Parasites of Sheep and Goats in Tulus Area Based on Post-Mortem Examination. Asian Journal of Animal and Veterinary Advances, 3(6), 390-399. doi: 10.3923/ajava.2008.390.399.

Balicka-Ramisz, A., Ramisz, G., \& Zychlińska-Buczek, J. (2013). The annual population dynamics of gastrointestinal nematodes in breeding sheep of the Silesian Foothills, southern Poland. Annals of Parasitology, 59(4), 163-167. URL: https://pubmed.ncbi.nlm.nih.gov/24791341.

Banerjee, R., Mandal, P. K., Bose, S., Banerjee, M., \& Manna, B. (2009). Quality evaluation of meat, skin and wool from Garole sheep - a promising breed from 
India. Asian Journal of Animal Sciences, 3, 39-46. doi: 10.3923/ajas.2009.39.46.

Believ, S-M. M., Ataev, A. M., \& Gazimagomedov, M. G. (2012). The spread of helminths and helminthiases of sheep in the Caspian region. Problems of Development of Agro-Industrial Complex of the Region, 2(10), 89-94.

Bohach, M. V., Bohach, T. V, Bondarenko, L. V., \& Piven, O. T. (2015). Age dynamics of intestinal parasitosis diseases of sheep in the farms of Odessa region. Problems of Zooengineering and Veterinary Medicine, 30(2), 213-217.

Boyko, A. A. (2015). Helmintofauna of sheep and goats in Dnipropetrovsk region. Visnyk of Dnipropetrovsk University. Biology, Medicine, 6(2), 87-92. doi: $10.15421 / 021516$.

Byrka, V. I., \& Berezovskyi, A. V. (2003). Parasitofauna of young sheep. Problems of Zooengineering and Veterinary Medicine, 11(35), 72-75.

Cabaret, J., Mage, C., \& Bouilhol M. (2002). Helminth intensity and diversity in organic meat sheep farms in centre of France. Veterinary Parasitology, 105(1), 3347. doi: 10.1016/s0304-4017(01)00647-1.

Eslami, A., Meydani, M., Maleki, S., \& Zargarzadeh, A. (1979). Gastrointestinal nematodes of wild sheep (Ovis orientalis) from Iran. Journal of Wildlife Diseases, 15(2), 263-265. doi: 10.7589/0090-355815.2.263

Gupta, R. P., Yadav, C. L., \& Chaudhri, S. S. (1987). Epidemiology of gastrointestinal nematodes of sheep and goats in Haryana, India. Veterinary Parasitology, 24(1-2), 117-127. doi: 10.1016/0304-4017(87)90136-1.

Ibrahim, N., Tefera, M. M., Bekele, M., \& Alemu, S. (2014). Prevalence of gastrointestinal parasites of small ruminants in and Around Jimma Town, Western Ethiopia. Acta Parasitologica Globalis, 5(1), 26-32.

Idris, A., Moors, E., Sohnrey, B., \& Gauly, M. (2011). Gastrointestinal nematode infections in German sheep. Parasitology Research, 110(4), 1453-1459. doi: 10.1007/s00436-011-2648-1.

Ivashkin, V. M., Kontrimavichus, V. L., \& Nazarova, N. S. (1971). Metody sbora i izuchenija gel'mintov nazemnyh pozvonochnyh [Methods for collection and study of helminthes of terrestrial mammals]. Nauka, Moscow (in Russian).

Ivashkin, V. M., Oripov, A. O., \& Sonin, M. D. (1998). Opredelitel' gel'mintov melkogo rogatogo skota [Key to the helminthes of caprine cattle]. Nauka, Moscow (in Russian).

Kanyari, P. W., Kagira, J. M., \& Mhoma, R. J. (2009). Prevalence and intensity of endoparasites in small ruminants kept by farmers in kisumu municipality, Kenya. Livestock Research for Rural Development, 21(11), 111-116. URL: http://www.lrrd.org/lrrd21/ 11/kany21202.htm.

Kovalevskaja, E. O., Artykov, G. T., \& Dimitriadi, A. P. (2016). Some issues of epizootology of intestinal nematodes of sheep in the conditions of the northeastern region of the Republic of Belarus. Modern Technologies of Agricultural Production, 44-46.
Mederos, A., Fernández, S., van Leeuwen, J., Peregrine, A. S., Kelton, D., Menzies, P., LeBoeuf, A., \& Martin, R. (2010). Prevalence and distribution of gastrointestinal nematodes on 32 organic and conventional commercial sheep farms in Ontario and Quebec, Canada (2006-2008). Veterinary Parasitology, 170(3-4), 244-252. doi: 10.1016/ j.vetpar.2010.02.01838.

Melnychuk, V. V., \& Berezovsky, A. V. (2018). Comparative embryonic development of nematodes of the genus Trichuris (Nematoda, Trichuridae) obtained from sheep (Ovis aries). Biosystems Diversity, 26(4), 257-262. doi:10.15421/011839.

Morgan, E. R., \& van Dijk, J. (2012). Climate and the epidemiology of gastrointestinal nematode infections of sheep in Europe. Veterinary Parasitology, 189(1), 8-14. doi: 10.1016/j.vetpar.2012.03.028.

Pavlovic, I. (2017). Biodiversity of helminths of sheep breed in Vojvodina (Northern Serbia). Bulletin UASVM Veterinary Medicine, 74(2), 162-166. doi: 10.15835/buasvmen-vm:0011.

Ramos, C. I., Bellato, V., de Souza, A. P., de Avila, V. S., Coutinho, G. C., \& Dalagnoll, C. A. (2004). Epidemiology of sheep gastrintestinal helminthosis in "Planalto Catarinense" Region, Brazil. Ciência Rural, 34(6), 1889-1895.

Salmanova, M. M., \& Gairabekov, R. H. (2013). Fauna of gastrointestinal strongylates of sheep and goats on the territory of the Chechen republic. South of Russia: ecology, development, 8(3), 73-75. doi: 10.18470/1992-1098-2013-3-73-75.

Shankute, G., Bogale, B., \& Melaku, A. (2013). An abattoir survey on gastrointestinal nematodes in sheep and goats in Hemex-Export abattoir, Debre Ziet, Central Ethiopia. Journal of Advanced Veterinary Research, 3(2), 60-63. URL: https://www.advetresearch.com/index.php/AVR/ article/view/116.

Skrjabin, K. I. (1928). Metod polnyh gel'mintologicheskih vskrytij pozvonochnyh, vkljuchaja cheloveka [The method of complete helminthological autopsy of vertebrates, including humans]. Moscow State University, Moscow (in Russian).

Skrjabin, K. I., Shikhobalova, N. P., \& Shults, R. S. (1954). Osnovy nematodologii. Trihostrongilidy zhivotnyh i cheloveka [Essentials of nematology. Trichostrongylids of animals and man]. Nauka, Moscow (in Russian).

Terentieva, Z. H. (2011). Fauna of parasites and dynamics of invasions in sheep and goats in the South Urals. Proceedings of the Orenburg State Agrarian University, 3(31), 374-377.

Thieltges, D. W., Jensen, K. T., \& Poulin, R. (2008). The role of biotic factors in the transmission of free-living endohelminth stages. Parasitology, 135(4), 407-26. doi:10.1017/S0031182007000248.

Tigist, K., Jemere, B., \& Desie, Sh. (2015). Gastrointestinal nematodes of sheep and goats in three districts of Kaffa and Bench Maji Zones, Southwest Ethiopia. Ethiopian Veterinary Journal, 19(2), 67-76. doi: 10.4314/evj.v19i2.6. 
Vlasenko, O. V., \& Stybel, V. V. (2012). Epizootological situation from invasive diseases in sheep farms of Sumy region. Scientific Messenger of LNU of Veterinary Medicine and Biotechnologies. Series "Veterinary Sciences", 14(2(52)), 44-48.

Vlassoff, A., Leathwick, D. M., \& Heath, A. C. (2001). The epidemiology of nematode infections of sheep. New Zealand Veterinary Journal, 49(6), 213-221. doi: 10.1080/00480169.2001.36235.

Waruiru, R. M., Thamsborg, S. M., Nansen, P., Kyvsgaard, N. C., Bogh, H. O., Munyua, W. K., \& Gathuma, J. M. (2001). The epidemiology of gastrointestinal nematodes of dairy cattle in central Kenya. Tropical Animal Health and Production, 33(3), 173-187. doi: 10.1023/a:1010322703790.

Wilmsen, M. O., Silva, B. F., Bassetto, C. C., \& Amarante, A. F. T. (2014). Gastrointestinal nematode infections in sheep raised in Botucatu, state of São
Paulo, Brazil. Revista Brasileira de Parasitologia Veterinária, 23(3), 348-354. doi: 10.1590/S198429612014058.

Yevstafieva, V. O., Hryshko, A. O., \& Perebyinis, O. V. (2016). Nematodiris in the composition mixed invasion of the digestive canal of sheep in the conditions farms of Poltava region. Problems of Zoinengineering and Veterinary Medicine, 33(2), 131-134.

Yevstafieva, V. A., Yuskiv, I. D., Melnychuk, V. V., Yasnolob, I. O., Kovalenko, V. A., \& Horb, K. O. (2018). Nematodes of the Genus Trichuris (Nematoda, Trichuridae) Parasitizing Sheep in Central and South-Eastern Regions of Ukraine. Vestnik Zoologii, 52(3), 193-204. doi: 10.2478/vzoo-2018-0020. 